\title{
Accounting
}

\section{The role of commercial banks on economic growth in Vietnam}

\author{
Nguyen Thi Hong Anh ${ }^{a^{*}}$
}

\begin{tabular}{l}
${ }^{a}$ Industrial University of Ho Chi Minl \\
\hline C H R O N I C L E \\
\hline Article history: \\
Received May 182020 \\
Received in revised format May \\
262020 \\
Accepted July 182020 \\
Available online \\
July 182020 \\
\hline Keywords: \\
Commercial bank development \\
Economic growth \\
Vietnam
\end{tabular}

\section{Introduction}

Economists point out that sustainable economic growth depends heavily on improving the ability to accumulate physical and human capital, so resources in the economy will be used more effectively. Economists also demonstrate that financial development is a necessary condition for achieving high economic growth. Patrick (1966) calls this the supply-leading role of financial development. The supply-leading hypothesis that a well-developed financial sector will facilitate financial transactions, savings mobilization, and allocation of deposits to developed domestic economic activities. Financial development plays a role in stimulating economic growth when allocating financial resources and appropriate financial needs to people in the economy that need capital to stimulate economic growth (Levine, 1997; Le \& Vo, 2020). Calomiris and Hubbard (1990) discussed that low financial development results in inefficient credit allocation or poor loan quality and, therefore, can have a negative effect on economic growth development. Nowadays, there are more than 50 countries with gross domestic product (GDP) per capita less than five thousand dollars in the world, which shows that the key to economic growth is still an important issue. Vietnam's economy has made changes in the past 20 years and especially in the last 10 years. Vietnam's economic growth in 2018 reached $7.08 \%$ compared to 2017 - the highest increase in 11 years. Unemployment and underemployment tend to decrease. In 2018 , Vietnam actively promoted free trade agreements and achieved many great achievements. Vietnam's import-export turnover in 2018 was increased by $13.6 \%$ compared to 2017 . Trade surplus reached 7.21 billion USD. Trade agreements will be the basis to help traditional Vietnamese industries such as textiles, footwear, seafood, furniture and have many opportunities to compete with the international market. Regarding the financial market, in 2018, M2 growth and credit growth tend to decrease. Credit growth in 2018 was increased by $14-15 \%, 3-4$ percentage points lower than 2017, partly due to the SBV's credit tightening

* Corresponding author.

E-mail address: nguyenthihonganh@iuh.edu.vn (N. T. H. Anh) 
policy in the second half. Interest rates on the deposit market of institutional and individual customers and the average lending rate have increased. Vietnam's economic growth is also a part of the development of commercial banks. Therefore, this study uses FEM and REM models to test the role of commercial bank development in economic growth in Vietnam.

\section{Overview of previous studies and approaches method}

Merton and Bodie (1995) argue that the degree of financial intermediation in the world affects the redistribution of financial resources. As the efficiency of the banking industry increases, the costs involved in obtaining financial information and transactions will decrease, resulting in an efficient allocation of credit. Similarly, with the development of the stock market and the bond market, people can get more opportunities for investment activities from the financial market than ordinary savings. Therefore, the imperfect credit market causes market imperfection and promotes the development of financial intermediation. Thus, a highly developed financial system will increase the efficiency of financial resource allocation, positively affecting economic growth. According to Boyd and Prescott (1986), a well-developed financial system will reduce information costs and capital allocation. This can improve the efficiency of allocation of funds to those who need capital to invest because of the reduced transaction costs if the financial system is weak (Hung \& Tuan, 2019). Therefore, it can be affirmed that the presence of financial intermediaries in mobilizing savings for lending has helped minimize investment costs, production and business in the economy. Greenwood and Jovanovic (1990) agree that the development of created financial intermediaries will reduce transaction costs and increase the efficiency of financial resource allocation, stimulate economic growth, because financial intermediaries development will enable more and more people to use financial services, helping financial intermediaries increasingly improve the quality and efficiency of resource allocation. On the other hand, if the financial market does not develop, it will hinder economic growth. Galor and Zeira (1993) have argued that a well-developed financial system reduces income inequality. Because, when the allocation of credit capital is inefficient, the investment in human capital is limited, and this, once again, accumulated human capital is negatively affected by the capital market. imperfect. That is the reason, imperfect financial markets will hinder economic growth. Patrick (1966) proposed two possible hypotheses in the causal relationship between development finance and economic growth. With the first theory, he argued that economic growth caused the expansion of the financial system and he called it demand-following. According to the demand-following hypothesis, when the economy grows, the demand for financial services will increase or in other words the lack of financial growth is an expression of the lack of demand for services. Under the second hypothesis, Patrick found that expanding the financial system to meet demand for services would foster economic growth called supply-leading. Using data from 56 countries, Jung (1986) found that the supply hypothesis is correct in underdeveloped countries and the demand push theory is true in developed countries. Thus, the role of growth for financial intermediaries may change at different stages of economic development. When the economy is in a period of transformation, the supply-pull hypothesis prevails, meaning that the development of financial intermediaries will promote economic growth. On the contrary, when the economy has developed, the demand-push hypothesis prevails, that is, the economy growth will lead to an increase in demand for financial services.

\section{Approach method}

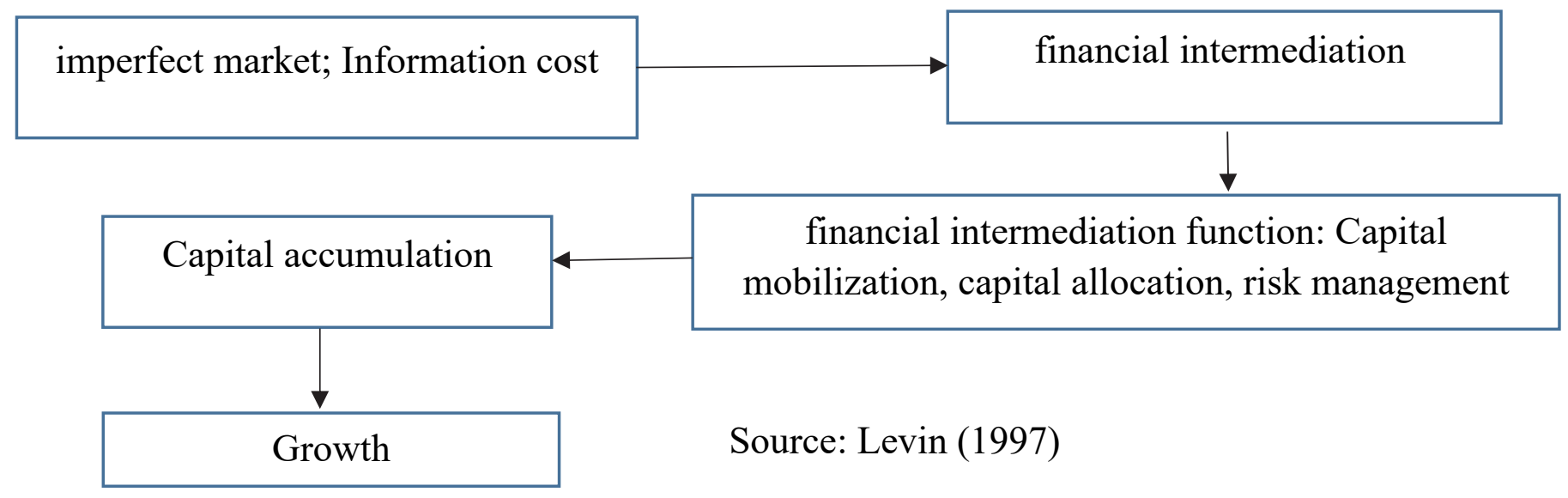

\section{Data and research model}

4.1 Data

The paper uses panel data from 2007 - 2018 and macro data is collected from the World Development Indicator (WDI) of the World Bank - WB) and other data collected from the annual report of 30 publicly listed Vietnamese commercial banks. The 
variables used in the model synthesized from previous studies are: Two variables of credit and deposit balances are used to measure the main activities of commercial banks (Greenwoood, 1990; Minh \& Thanh, 2020). When the bank operates effectively, it will well perform its financial intermediation function, allocating capital from surplus to shortage in the economy. Thus, stimulating economic growth (King \& Levine, 1993a). The non-performing loan variable is proved by Samolyk (1992) to have a significant effect on growth since this variable represents the quality of commercial bank loans. In addition, several studies have shown a positive association between inflation and economic growth (Hwang, 2001), while there are studies proving a negative relationship between these two variables (Arai et al., 2004; Adam \& Bevan, 2005). However, Nguyen (2010) and Andres and Hernando (1997) have demonstrated the causal relationship between these two variables. Therefore, in this paper, the author uses inflation as an exogenous variable in addition to the trade openness because since 1990, the banking industry in particular and the Vietnamese economy in general have had a strong imprint in promoting economic growth as well as Loizides (2004) have discovered that trade openness has a close relationship with economic growth. In which: OPE variable - Trade openness: calculated by the ratio of total value of export and import of goods and services to GDP; INF variable Inflation rate: measured by annual consumer price index growth, using macroeconomic stability assessment. It reflects the effectiveness of monetary policy and affects growth through the impact of economic and saving decisions on investment.

4.2 Research model: The study uses regression method with unbalanced panel data. According to King and Levine (1993b), Koivu (2002) the model is written as follows:

$$
G D P_{t}=\alpha+\beta_{1} C \mathrm{R} E+\beta_{2} D E P+\beta_{3} R O A+\beta_{4} R O E+\beta_{5} D \mathrm{RR}+\beta_{6} N I M+\beta_{7} N P L+\beta_{39} I N F+G D P_{t-1}+\varepsilon_{i t}
$$

where Table 1 shows the description and the variables used in the proposed model.

Table 1

The meaning and expectation of variables in the research model

\begin{tabular}{ll}
\hline $\begin{array}{l}\text { No. } \\
\text { Dependent variable }\end{array}$ & Meaning \\
GDP & Economic growth rate \\
\hline Independent variables & Credit balance / total assets ratio \\
CRE & Deposit balance / total assets ratio \\
DEP & Return On Asset \\
ROA & Return on equity \\
ROE & Risk provisioning levels \\
RPL & Net Interest Margin \\
NIM & Non-performing loan rate \\
NPL & Trade openness \\
OPE & Inflation rate \\
\hline INF & + \\
\hline
\end{tabular}

\section{Research results}

With the collected data and the proposed model, the study runs regression with panel data including FEM model and REM model. Regression results are obtained in Table 2.

Table 2

$\underline{\text { Regression results }}$

\begin{tabular}{|c|c|c|c|c|}
\hline & FEM & & REM & \\
\hline & $\beta$ & P_value & $\beta$ & P_value \\
\hline $\begin{array}{l}\text { Depende } \\
\text { GDP } \\
\text { Independ }\end{array}$ & & & & \\
\hline CRE & 0.8354244 & $0.039 * *$ & 0.6211704 & $0.014 * *$ \\
\hline DEP & -1.407012 & $0.000 *$ & -0.8595112 & $0.001 *$ \\
\hline ROA & 0.2461097 & $0.007 *$ & 0.218196 & $0.004 *$ \\
\hline ROE & -0.0054564 & 0.474 & -0.0019533 & 0.729 \\
\hline RPL & 14.35615 & 0.179 & 16.23398 & $0.032 * *$ \\
\hline NIM & -0.1847788 & $0.000 *$ & -0.1364621 & $0.000 *$ \\
\hline NPL & -0.091855 & $0.000 *$ & -0.0916854 & $0.000 *$ \\
\hline OPE & 0.0224508 & $0.000 *$ & 0.0210097 & $0.000 *$ \\
\hline INF & 0.0020995 & 0.693 & 0.0047518 & 0.325 \\
\hline Const & 3.266864 & 0.000 & 3.10792 & 0.000 \\
\hline R-sq & 0.6529 & & 0.7611 & \\
\hline $\mathrm{P}$ value & 0.000 & & 0.000 & \\
\hline
\end{tabular}

*** significance at $1 \%$ và $5 \%$ 
The regression results show that:

For the FEM model, the significant variables at the 1\% significance level are DEP, ROA, NIM, NPL, OPE and the 5\% significant variables are CRE. The fixed impact model has a relatively high significance when R-Square reaches $65.29 \%$ with $\mathrm{P}_{-}$value $=$ 0.000 .

For the REM model, the significant variables at the 1\% significance level are DEP, ROA, NIM, NPL, OPE and the 5\% significant variables are CRE, RPL. The fixed impact model is highly significant when R-Square reaches $76.11 \%$ with $\mathrm{P}_{-}$value $=0.000$.

In order to determine the FEM or REM more effectively in this study, the author continues to conduct Hausman test to select the appropriate model. The hypothesis with the Hausman test is as follows:

\section{$\mathrm{H}_{0}$ : Estimation of FEM and REM are not different \\ $\mathrm{H}_{1}$ : Estimates of FEM and REM are different}

\section{Table 3}

Hausman test results as follows

\begin{tabular}{lccc}
\hline & FEM & REM & Difference \\
\hline CRE & 0.8354244 & 0.6211704 & 0.214254 \\
DEP & -1.407012 & -0.8595112 & -0.5475008 \\
ROA & 0.2499027 & 0.218196 & 0.0317067 \\
RPL & 14.35615 & 16.23398 & -1.877827 \\
NIM & -0.1847788 & -0.1364621 & -0.0483166 \\
NPL & -0.091855 & -0.0916854 & -0.0001696 \\
OPE & 0.0224508 & 0.0210097 & 0.0014411 \\
INF & 0.0020995 & 0.0047518 & -0.0026522 \\
\hline
\end{tabular}

The Hausman test shows that $\mathrm{P}$ value $=0.1088>5 \%$ we conclude that there is no difference between the fixed effects model and the random effects model, which is statistically significant, that is, the hypothesis $\mathrm{H}_{0}$ no rejection was made so it was appropriate to choose a randomized impact model. Thus, the results of empirical research on the role of Vietnam commercial bank development in the 2007-2018 period for specific economic growth are as follows:

- The sign of the CRE variable in the model of random effects is consistent with the initial expectation of the study, meaning that the higher the ratio of credit to total assets of the bank, the more economic growth will be promoted. This is consistent with the reality in Vietnam because commercial banks are the channel to allocate credit capital of the economy while the stock market has not fully played its role.

- DEP variables are meaningful in both random effects models and fixed effects models. This is very suitable in practice because capital mobilization is an effective channel to attract idle capital in the population. However, DEP's mark contrasted with the original expectation of the paper.

- ROA and ROE variables are the two variables that measure the bank's performance. Regression results show that banking performance has an impact on economic growth in Vietnam. However, the return on equity is opposite to the initial expectations and makes no sense in both the random effects and the fixed effects. Through the ROA variable, the higher the performance of commercial banks, the greater the contribution to economic growth in Vietnam.

- The RPL variable is statistically significant in the REM selected model and has the mark exactly in accordance with the initial expectation. This can be easily understood because the increase in outstanding loans increases the amount of general provision of commercial banks.

- The NIM variable is statistically significant at the 1\% significance level for both FEM and REM models and is stamped as originally expected because the lower the rate of net interest income, indicating that commercial banks have accepting to sacrifice a part of profits from their business activities to provide capital for the economy, contributing to economic growth.

- The NPL variable is statistically significant at $1 \%$ and inversely proportional to the growth rate, indicating that when the economy grows effectively, the higher the loan quality, the lower the level of bad debt.

- Of the two macro variables OPE and INF, only the OPE variable is statistically significant at $1 \%$ and has an impact on economic growth. Show that the more the economy integrates, the more trade is opened, the higher the economic growth rate. 
The purpose of the study was to examine the role of commercial banking development in economic growth in Vietnam between 2007 and 2018 and has shown: Vietnamese commercial banks play an important role in contributing to promoting economic growth in the 2007-2018 period. Especially, the role of providing capital to the economy to invest in production and business infrastructure of domestic enterprises. Therefore, in the coming time, it is necessary to further promote the role of commercial banks, especially to expand and improve the quality of investment loans for the economy by:

- Enterprises need to make information transparent so that credit institutions can easily accept loans and disburse capital.

- Further develop non-cash payment methods in the economy. The non-cash payment will help businesses' revenues, expenses, etc. made through the bank's payment system will reduce the inconsistencies between financial statements sent to banks and reports. finance filed tax authorities. At the same time, the bank account statements of businesses will be more reliable and have a legal basis, which is the basis for commercial banks to use to assess the financial capacity of the business when appraising the problem. loan offer.

- Commercial banks need to diversify loan product packages suitable to each sector and region of the enterprise as well as loosen the conditions of loan procedures for businesses.

\section{References}

Adam, C. S., \& Bevan, D. L. (2005). Fiscal deficits and growth in developing countries. Journal of public economics, 89(4), 571-597.

Andres, J., \& Hernando, I. (1997). Does inflation harm economic growth? Evidence for the OECD, NBER Working Paper No. 6062, National Bureau of Economic Research, Cambridge, MA.

Arai*, M., Kinnwall, M., \& Thoursie, P. S. (2004). Cyclical and causal patterns of inflation and GDP growth. Applied Economics, 36(15), 1705-1715.

Boyd, J.H. \& Prescott, E.C. (1986). Financial intermediarycoalitions. Journal of Economics Theory, 38(2), 211-232.

Calomiris, C. W. \& Hubbard, R. G. (1990). Firm heterogeneity, internal finance, and credit rationing, Economic Journal of Royal Economic Society, 100(399), 90-104.

Galor, O. \& Zeira, J. (1993). Income distribution and macroeconomics. Review of Economic Studies, 60(1), 35-52.

Greenwood, J. \& Jovanovic, B. (1990). Financial development, growth, and the distribution of Income. Journal of Political Economy, 98(5), 1076-1107.

Hung, D., \& Tuan, T. (2019). Factors affecting the effectiveness of internal control in joint stock commercial banks in Vietnam. Management Science Letters, 9(11), 1799-1812.

Hwang, Y. (2001). Relationship between inflation rate and inflation uncertainty. Economics Letters, 73, 179-86.

Jung, W. S. (1986). Financial development and economic growth: International evidence. Economic Development and Cultural Change, 34(2), 333-346.

King, R. G. \& Levine, R. (1993a). Finance and growth: Schumpeter might be right. Quarterly Journal of Economics, 108(3), 717-737.

King, R. G. \& Levine, R. (1993b). Finance, entrepreneurship, and growth: Theory and evidence. Journal of Monetary Economics, 32(3), 513-542.

Koivu, T. (2002). Do efficient banking sectors accelerate economic growth in transition countries. Discussion Papers No. 14.

Levine, R. (1997). Financial development and economic growth: Views and agenda. Journal of Economic Literature, 35(2), 688-726.

Le, H., \& Vo, T. (2020). Concentration and performance in Vietnamese commercial banks. Accounting, 6(2), 161-168.

Loizides, J., \& Vamvoukas, G. (2004) Government expenditure and economic growth: Evidence from trivariate causality testing, Journal of Applied Economics, 8(1), 125-152

Merton, R.C. \& Bodie, Z. (1995). A Conceptual framework for analyzing the financial environment. In Crane, D.B., et al. (Eds.), The Global Financial System: A Functional Perspective. Harvard Business School Press, Boston, MA, pp. 3-31.

Minh, S., \& Thanh, T. (2020). Analysis of the impact from non-interest income to the operational efficiency of commercial banks in Vietnam. Management Science Letters, 10(2), 455-462.

Nguyen, T. T., \& Wang, K. (2010) Causality between housing returns, inflation and economic growth with endogenous breaks, Journal of Chinese Economic and Business Studies, 8, 95-115.

Patrick, H. (1966). Financial development and economic growth in underdeveloped countries. Economic Development and Cultural Change, 14(6), 174-189.

Samolyk, K. A. (1992). Banking conditions and regional economic performance: Evidence of a regional credit channel. Journal of Monetary Economics, 34(2), 259-278. 


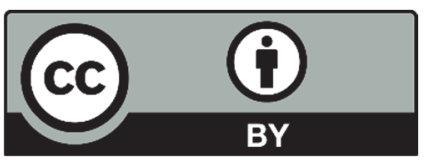

(C) 2020 by the authors; licensee Growing Science, Canada. This is an open access article distributed under the terms and conditions of the Creative Commons Attribution (CC-BY) license (http://creativecommons.org/licenses/by/4.0/). 